\title{
The Effect Of Back Massage Therapy On Rheumatic Pain In The Elderly In The Geriatric Clinic Kesdam Cijantung Hospital, East JakartaYear 2019
}

\author{
Susilowati $^{1}$, Fajar Susanti², Samsuni ${ }^{3}$
}

\begin{abstract}
Rheumatic disease is a chronic joint inflammatory disease caused by an autoimmune disorder. Pain is a clinical complaint most frequently encountered by nurses. This study aims to determine the comparison of the results of back message therapy and not back message therapy with pain in elderly rheumatism. This study is a quantitative study with a quasi-experimental research design made using a non-equivalent group design with pre and post tests. The research sample was 18 respondents. The sampling technique used purposive sampling. Data collection using experimental method. The instrument for measuring the level of pain uses a numerical rating scale (NRS). From the results of statistical analysis using the Independent Sample Test, it is known that the average difference in the measurement results of back message therapy in the pre category of 5.22 and post is 2.00 with $\mathrm{p}$ value $=0.000$ $(<0.05)$, while there is a difference of pre 5,17 and post 3.50 on no back message therapy which obtained $\mathrm{p}$ value $=$ $0.000(<0.05)$. It was concluded that there was a significant difference in pain in elderly arthritic patients who took back message therapy and did not follow back message therapy. It is important for the results of this study that health workers teach back message therapy for the elderly who experience pain because this is a very effective therapy for people with rheumatism.
\end{abstract}

Keywords: Back Message, Rheumatic Pain, Elderly

\section{Background}

The aging process is a progressive accumulation of various pathophysiological changes in the body's organs that take place over time which can increase the risk of developing degenerative diseases to death. The aging process takes place naturally in the body which takes place continuously and continuously, subsequently causing anatomical, physiological and biochemical changes in body tissues which ultimately affect overall physical abilities (Sudirman, 2011). The increase in the number of elderly people in several countries, one of which is Indonesia, has changed the population profile both nationally and globally. The results of the 2010 population census showed that the number of elderly people in Indonesia amounted to 18.57 million people, an increase of about $7.93 \%$ from in 2000 which was 14.44 million people. It is estimated that the number of elderly people in Indonesia in 2025 the number of elderly people in Indonesia will continue to grow by around 450,000 people per year. Thus, in 2025 the number of elderly people in Indonesia will be around 34.22 million people (Budi, 2010).

As a result of aging occurs in various body systems, one of which is rheumatic disease. Rheumatism is a non-bacterial inflammatory disease that is systemic, progressive, tends to be chronic and affects joints and joint connective tissue symmetrically. (Chairuddin, 2010). This decline in physical ability is caused by the presence of various kinds of diseases that begin to attack, including rheumatism. Rheumatism is a non-specific term to describe various complaints and disorders that affect the locomotor system

It involves joints, muscles, connective tissue, soft tissue around joints and bones. Any complaints of joint and bone pain, can be referred to as rheumatic complaints (Faisal, 2009).

Rheumatic disease is a chronic joint inflammatory disease caused by an autoimmune disorder. An autoimmune disorder occurs when the body's immune system functions as a defense against intruders such as viruses, bacteria, and fungi. Rheumatic disease, commonly known as arthritis (arthritis) and considered a single condition, actually consists of more than 100 different types of disorders. This disease mainly affects skeletal muscles, bones, ligaments, tendons and joints in men and women of all ages. Some disorders are more likely to occur at a certain time in the patient's life or affect one sex more than the other. The impact of this condition can be lifethreatening for the sufferer or only cause discomfort, and the problems caused by rheumatic diseases are not only in the form of obvious limitations on mobility and activities of daily living 
but also systemic effects that are not clear but can lead to organ failure and death or even death. cause problems such as pain. Fatigue, changes in selfimage and sleep disturbances (Kisworo, 2008). Rheumatic diseases are divided into 2 types, namely rheumatoid arthritis and rheumatoid arthritis (Adellia, 2011).

The incidence of rheumatism in the elderly in 2015 reported by the World Health Organization (WHO) reached $20 \%$ of the world's population who had rheumatism, of which $5-10 \%$ were those aged 5-20 years and 20\% were those aged 55 years. the highest disease in the elderly in Indonesia is rheumatic disease with a percentage value of $49 \%$ and the disease is more common in women than in men (Wiyono, 2016).

Pain is a clinical complaint most frequently encountered by nurses. Nurses have a very important role in pain management so that patients can achieve a sense of comfort by using various pain relief techniques. Joint pain must be diagnosed quickly to be able to distinguish between infectious causes and inflammatory rheumatic joint disease. In many cases, specific therapy is urgently needed. to avoid the bad consequences that accompany joint damage. In addition to a detailed history and an inclusive family history of the disease, the character of the pain, the onset and clinical course of joint pain, the age at onset of the clinical picture, the pattern of disease attacks on the joints, general symptoms, changes in the skin and mucosa, eyes, internal organs, and systems of the body. Neurological examination, blood tests, obvious clinical manifestations and on the interest of synovial examination can provide clues about the disease. The causes can be from inflammation, degenerative, infection, metabolic, and rheumatic (Kisworo, 2010).

While there are many different types of medications to relieve pain, they all have risks and costs.
Fortunately, there are many non-pharmacological interventions that can help relieve pain. Various attempts to reduce pain in rheumatism, both pharmacologically and non-pharmacologically. As is the case with non-pharmacological massage, back massage is one of the most preferred and most common types of massage therapy. The back massage is just one of those amazing experiences guaranteed relieve stress from the body. With the correct back massage technique, you will get maximum results. The massage will create mental fitness after the body and mind relax. The feeling of being younger again will also be felt along the previously tense back muscles. Muscle fibers that were previously stiff and tense will become flexible so that in turn blood circulation will be smoother. This massage is best when using a lubricating fluid to minimize the essentials with a calming aroma (Tamsuri, 2012).

Massage and touch are sensor integration techniques that affect the activity of the autonomic nervous system. If the individual perceives touch as a stimulus to relax, then a relaxation response will appear. Relaxation is very important in helping clients to increase comfort and free themselves from fear and stress due to illness and endless pain (Potter \& Perry, 2010). Back Massage is a technique of providing massage on the back with slow strokes. Rub with lotion/balm provides a warm sensation by causing dilation of local blood vessels. Vasodilation of blood vessels will increase blood circulation in the rubbed area so that cell activity increases and will reduce pain and support the wound healing process (Kusyati, 2010).

The sensation of warmth can also increase the feeling of comfort. Other therapeutic values of back massage include reducing muscle tension and increasing physical and psychological relaxation (Kusyati, 2010). Previous research conducted by Thomas (2012) with the title the effect of back massage therapy on the intensity of rheumatic pain in the elderly in the area of Karang Asem Panjang Public Health Center, 
Surakarta, with the results showing that before being given back massage, 5 respondents experienced mild pain on a scale of 1-3, 8 respondents experienced moderate pain on a scale of 4-6. After being given a back massage, there were 2 respondents who experienced moderate pain and 11 respondents experienced mild pain with a pain intensity of 1-3. The results of the Wilcoxon Signed Ranks Test have an average pre-test of 4.00 and an average post-test of 2.69 . The $\mathrm{Z}$ score $=-3,017$ with $\mathrm{p}$ value $=0.003$ means that there is an influence between back massage therapy on reducing the intensity of rheumatic pain in the elderly in the Pustu Karang Asem area.
From these data, it can be concluded that the results of the research that I got from the study showed that there was an effect of back massage therapy for rheumatism sufferers. So it is necessary to do back massage in rheumatic patients at home with the help of other people (family) to reduce the pain that arises.

\section{Research Method}

\subsection{Research design}

The research design is a research scheme created so that it can be used as a reference to obtain answers to the questions of researchers Sastroasmoro \& Ismail, 2014. This study is a quasiexperimental study made using a nonequivalent group design with pre and post tests. This study was to test the intervention of the effect of back massage therapy on rheumatic pain in the elderly in the geriatric poly, Sugiyono, 2017. 
1.1. Place and Time of Research This research was conducted at Tk Hospital. IV Cijantung Kesdam Jaya. Time The research will be carried out from October 2019 to February 2020 at Tk. IV Cijantung Kesdam Jaya.

\subsection{Population and Sample}

The population in this study were patients with rheumatism. At Tk Hospital. IV Cijantung Kesdam Jaya from August 20 people, September 15 people and October 15 people with a total of 50 people.

In this study, the determination of the number of samples used was non-pobability sampling with the consecutive sampling method. The purposive sampling method is a sampling method by selecting all respondents encountered who meet the inclusion criteria until the number of samples is determined (Dharma, 2015). The sample in this study were patients with rheumatism at Tk Hospital. IV Cijantung Kesdam Jaya.

\subsection{Data analysis}

Univariate analysis aims to explain or describe the characteristics of each research variable. Bivariate analysis in this study to determine the effect of back massage therapy on the elderly using the Independent $\mathrm{T}$ Test test if the data distribution is normal because the types of data used are categorical and numerical.

\section{Research Results}

\subsection{Univariate Analysis}

The number of samples in this study were 36 elderly arthritic patients who took back message therapy and did not follow back message therapy, each of 18 patients. Research conducted at
Poli Geriatrics Hospital Tk. IV Cijantung Kesdam Jaya in the range of December-January 2020. The following presents the results of a univariate analysis for rheumatic data in the elderly who took back message therapy and did not follow back message therapy in table form.

3.1.1. Back Message Therapy for Rheumatism Patients in the Elderly In Geriatrics Poly, Tk Hospital. IV Cijantung Kesdam Jaya

Table. 3.1.1. Frequency Distribution of Back Message Therapy for Rheumatism Patients in the Elderly In Geriatrics Polyclinic, Tk Hospital. IV Cijantung Kesdam Jaya $(\mathrm{N}=18)$. No Back Message Therapy for Rheumatism Patients in the Elderly In Geriatrics Poly, Tk Hospital. IV Cijantung Kesdam Jaya

\begin{tabular}{cccccc}
\hline $\begin{array}{c}\text { Kategori } \\
\text { Pre Tidak } \\
\text { Back }\end{array}$ & $\begin{array}{c}\text { Freku } \\
\text { ensi }\end{array}$ & $\begin{array}{c}\text { Presen } \\
\text { tase }\end{array}$ & $\begin{array}{c}\text { Kategori } \\
\text { Post Tidak } \\
\text { Back } \\
\text { Message }\end{array}$ & $\begin{array}{c}\text { Frekue } \\
\text { nsi }\end{array}$ & $\begin{array}{c}\text { Presen } \\
\text { tase }\end{array}$ \\
$\begin{array}{c}\text { 40 Menit } \\
\text { Efektif }\end{array}$ & 12 & 66 & 20 Menit & 4 & 22,2 \\
\hline $\begin{array}{c}\text { 20 Menit } \\
\text { Efektif }\end{array}$ & 6 & 33 & 40 Menit & 14 & 77,8 \\
Total & 18 & 10 & Total & 18 & 100 \\
& & 0 & & & \\
\hline
\end{tabular}

Table 3.1.2 Frequency Distribution of Back Message Therapy for Rheumatism Patients in the Elderly in Geriatric Polyclinic, Tk Hospital. IV Cijantung Kesdam Jaya ( $\mathrm{N}=18)$

\begin{tabular}{|c|c|c|c|c|c|}
\hline $\begin{array}{l}\text { Kategori } \\
\text { Pre Tidak } \\
\text { Back } \\
\text { Message } \\
\end{array}$ & $\begin{array}{l}\text { Frekue } \\
\text { nsi }\end{array}$ & $\begin{array}{l}\text { Prese } \\
\text { ntase }\end{array}$ & $\begin{array}{l}\text { Kategori } \\
\text { Post Tidak } \\
\text { Back } \\
\text { Message } \\
\end{array}$ & $\begin{array}{l}\text { Frekuen } \\
\text { si }\end{array}$ & $\begin{array}{l}\text { Presen } \\
\text { tase }\end{array}$ \\
\hline $\begin{array}{l}40 \text { Menit } \\
\text { Efektif }\end{array}$ & 12 & 66,7 & 20 Menit & 4 & 22,2 \\
\hline $\begin{array}{l}20 \text { Menit } \\
\text { Efektif }\end{array}$ & 6 & 33,3 & 40 Menit & 14 & 77,8 \\
\hline Total & 18 & 100 & Total & 18 & 100 \\
\hline
\end{tabular}




\subsection{Bivariate Analysis 1.1.1. Data Normality Test}

Table 3.2.1 Normality Test Results of Pain Data for Rheumatic Patients in the Elderly With Kolmogorov-Smirnov and Skewness Test

\begin{tabular}{llllll}
\hline & Mean & $\begin{array}{l}\text { Standar } \\
\text { Deviasi }\end{array}$ & $\begin{array}{l}\text { Asymp.Sig 2 } \\
\text { Table }\end{array}$ & Skewnes & $\begin{array}{l}\text { Std } \\
\text { Error }\end{array}$ \\
\hline Pre BM & 6.50 & 1.978 & $.200 \mathrm{c}, \mathrm{d}$ & .231 & .536 \\
\hline Post BM & 1.67 & 1.283 & $.149 \mathrm{c}, \mathrm{d}$ & .334 & \\
\hline & & & & & \\
\cline { 1 - 2 } $\begin{array}{l}\text { Pre tidak } \\
\text { BM }\end{array}$ & 6.50 & 1.724 & $.183 \mathrm{c}, \mathrm{d}$ & .271 & \\
\cline { 1 - 1 } $\begin{array}{l}\text { Post tidak } \\
\text { BM }\end{array}$ & 5.06 & 1.211 & $.063 \mathrm{c}, \mathrm{d}$ & .329 & \\
\hline
\end{tabular}

\subsubsection{T-Test Result Test}

Table 3.2.2 Normality Test Results of Pain Data in Rheumatic Patients in the Elderly With KolmogorovSmirnov And Skewness Test

\begin{tabular}{|c|c|c|c|c|c|c|}
\hline Variable & $\begin{array}{l}\text { Nyeri } \\
\text { Rematik } \\
\text { pada } \\
\text { lansia }\end{array}$ & Mean & $\begin{array}{l}\text { Standar } \\
\text { Deviasi }\end{array}$ & $\begin{array}{l}\text { Standar } \\
\text { Error }\end{array}$ & $\mathrm{N}$ & $\begin{array}{l}\mathrm{P} \\
\text { Value }\end{array}$ \\
\hline \multirow{3}{*}{$\begin{array}{l}\text { Terapi } \\
\text { back } \\
\text { message }\end{array}$} & $\begin{array}{l}\text { pre back } \\
\text { message }\end{array}$ & 5.22 & 1.166 & .275 & 18 & 0,000 \\
\hline & - & 2.00 & 1.029 & .243 & 18 & \\
\hline & $\begin{array}{l}\text { Post back } \\
\text { message }\end{array}$ & & & & & \\
\hline \multirow{2}{*}{$\begin{array}{l}\text { Tidak } \\
\text { terapi } \\
\text { back } \\
\text { message }\end{array}$} & $\begin{array}{l}\text { Pre tidak } \\
\text { back } \\
\text { message }\end{array}$ & 5.17 & 1.043 & .246 & 18 & \\
\hline & $\begin{array}{l}\text { - Post } \\
\text { tidak } \\
\text { back }\end{array}$ & 3.50 & .618 & .146 & 18 & \\
\hline
\end{tabular}

\section{DISCUSSION}

\subsection{Univariate Discussion}

2.1.1. Back Massage Therapy for Rheumatism Patients in the Elderly

The results of research conducted at the $\mathrm{Tk}$ Hospital. IV Cijantung Kesdam Jaya, obtained 36 rheumatic patients who follow back massage therapy. Based on the results of the first measurement of pain when doing back message therapy for rheumatic patients in the elderly who follow back message therapy at the Geriatric Poly Hospital Tk. IV Cijantung Kesdam Jaya, from a total of 18 respondents, the first pre-back message data was obtained from 13 patients $(72.2 \%)$ in the 40 -minute category, 5

patients $(27.8 \%)$ category 20 minutes . on post back messages with results in the 20 minute category as many as 14 patients $(77.8 \%)$,

category of 40 minutes into 4 patients $(22.2 \%)$. From the results of the study there was a decrease in rheumatic pain in the elderly when doing back message therapy in the 20 minute category.

Back massage is a massage using a touch of the hand in the back area with lotion/balm that can provide a warm sensation and cause local blood vessel dilation. Back massage serves to relieve pain, works by encouraging the release of endorphins so that it blocks the transmission of painful stimuli. The warm sensation of back massage can also increase comfort. Back massage is carried out for about 10 minutes to get maximum results in reducing pain complaints (Tamsuri, 2010).

Research related to the effect of back massage on pain levels in farmer groups by Dewi Kusuma (2018), the results obtained were the most low back pain levels in respondents with mild pain category as many as 23 people with an average of 1.90. From the results of the study above, it was seen that there was mild pain in patients who had back massage.

Complaints of pain can affect happiness, hope, peace of mind, ability to feel the satisfaction of life and enjoy life. Other disorders can be a decrease in activity and non-compliance in the process of care and treatment. This problem requires solving in an effort to assist the patient in adapting to the problem or pressure he feels. When patients complain of pain, then there is only one thing they want, namely to reduce pain or pain. This is natural because pain is the worst torture that reduces the will to achieve something in life, even becomes a frightening and unpleasant experience due to inadequate pain management. Severe pain and sudden attacks if not treated immediately. Measurement of pain prior to back massage therapy showed that the respondent was still able to indicate the location of the pain, then described the pain felt, and could follow the instructions ordered. 1.1.2. No Back Massage Therapy for Rheumatism Patients in the Elderly

The results of research conducted at the Tk Hospital. IV Cijantung Kesdam Jaya, obtained data based on pain in rheumatic patients in the elderly who did not follow back message therapy, from a total of 18 respondents obtained data on patients who did not follow back message therapy in pre back message 12 patients $(66.7 \%)$ category

40 minutes, 6 patients (33.3\%) category 20 minutes. In 
back message post therapy, there is no back message therapy 4

patients $(22.2 \%)$ category 20 minutes, 14 patients $(77.8 \%)$ in the 40-minute category. From the results above, pain occurs when elderly rheumatic patients do not receive back message therapy, which increases in the 40 minute category in pre and post.

Research related to the effect of back massage on pain levels in farmer groups by Dewi Kusuma (2018), obtained the results of the level of pain that was not given back massage at most respondents with moderate pain as many as 22 people with an average of 4.73. From the results of the study above, the pain that appears is moderate pain in the farmer group.

\subsection{Bivariate Discussion}

To test the difference in the mean of the two groups of data, a $\mathrm{T}$ test was used with the Independent T-test method. The average of the two data groups is said to be the same if the significance of the t test statistic (sig) is greater than the level of significance $(\alpha)$ determined in this study. alpha $(\alpha)=5 \%=$ 0.05 . Based on the results of the research data, it was found that the back message therapy data for pure rheumatic patients who took back message therapy and did not follow back massage therapy from 18 patients, the results of statistical tests obtained $p$ value in the second measurement $=0.000$, because the $\mathrm{p}$ value it can be concluded that the average There is a significant difference between those who follow back massage therapy and those who do not follow back massage therapy. Based on the difference test above, it can be concluded that the difference between following therapy and not following back massage therapy. Based on the results of research that has been done statistically there are

the difference that follows therapy and does not follow back massage therapy in rheumatic patients significantly. The difference is clearly seen from the measurement results who follow therapy and those who do not follow back massage therapy. These differences occur due to many factors, when compared to arthritic patients with different levels of pain scale. Pharmacological and non-pharmacological management of rheumatism can be successful with good cooperation between health care workers and patients, things that happen in the field in arthritic patients who do not follow back massage therapy, many patients are lazy to ask their family members to do back massage therapy. In rheumatic patients who follow back massage therapy have a pain scale in a better direction, the back massage therapy program that is undertaken is able to significantly reduce the pain scale through activities that are applied with this nonpharmacological administration. It is hoped that rheumatic patients in the elderly will carry out a back massage therapy program in a disciplined manner in order to give positive results and not provide complications, researchers hope that patients who have not done back massage therapy can do so in the future with the help of family members at home.

\section{Conclusion 5.1.Conclusion}

After doing research on the difference in pain in rheumatic patients in the elderly who follow back message therapy and do not follow back message, it can be concluded that pain in arthritic patients in the elderly who follow back message therapy

better than those who did not follow back message therapy. There is a significant difference in the pain of arthritic patients who follow back message therapy and those who do not follow back message therapy at the Geriatric Poly Hospital Tk. IV Cijantung Kesdam Jaya, the $p$ value of pain in rheumatic patients who took back message therapy was 0.000 or $<0.05$ then $\mathrm{H} 0$ was rejected, which means that there is a difference between the pain of arthritic patients in the elderly who follow back message therapy and those who do not follow back message therapy. .

\subsection{Suggestion}

\subsubsection{For Hospital}

The results of the study are suggested to be used as a basis so that in the future there will be counseling related to the influence of back message therapy to health workers at the Geriatric Poly and other rooms at the Kindergarten Hospital. IV Cijantung Kesdam Jaya as one of the non-pharmacological treatment 
counseling for rheumatism patients so that they can

improve health status for the elderly, especially in rheumatic patients.

\subsubsection{For Nurse}

The results of this study are recommended for nurses to teach more back message therapy to the elderly who come to the geriatric polyclinic and the elderly who are anywhere.

\subsubsection{For Educational Institutions The} results of this study are recommended for institutions to include back message material into the learning curriculum, especially in Human Basic Nursing material to increase students' knowledge and insight in pain management.

5.2.4. For Further Researchers This research can be used as material in continuing research related to similar themes using other related variables and also for further researchers it is recommended to provide more explanations about back messages so that they can contribute more in research and it is expected that results This research can be a reference and reference for further researchers.

\section{Bibliography}

Adhiyati, Sri. 2011. Pengaruh Stimulus Kutaneus Slow-Stroke Back Massage terhadap Intensitas Nyeri Pada Penderita Low Back Pain (LBP) diKelurahan Aek Gerger Sidodadi. Universitas Sumatera Utara. http://repository.usu.ac.id/bitstream /123456789/24616/7/Cover.pdf diakses 9 desember 2019

Berman, Snyder, Kozier, Erb. 2010. Buku Ajar Praktik Keperawatan Klinis Kozier \& Erb edisi 5. Jakarta: EGC Dahlan, Sopiyudin. 2011.
Statistik Untuk Kedokteran dan Kesehatan. Jakarta : Salemba Medika. https://books.google.co.id/books?id $=\mathrm{Abh} 5 \mathrm{OaO} 3 q \mathrm{MC} \&$ printsec $=$ front cover\&dq=statistik+kesehatan\&hl= id\&sa $=X \&$ redir esc $=\mathrm{y} \# \mathrm{v}=$ onepage $\& \mathrm{q}=$ statistik $\% 20 \mathrm{keseh}$ atan $\& \mathrm{f}=$ false diakses 10 desember 2019

Endah, K. 2013. Penambahan Terapi Latihan Mc.Kenzie Pada Intervensi Short Wave Diathermi (SWD), Transcutaneus Electrical Nerve Stimulation (TENS), dan Massage Untuk Dapat Lebih Menurunkan Nyeri Pinggang Pada Kasus Low Back Pain. Denpasar : Universitas Udayana. http://ojs.unud.ac.id/index.php/mifi /article/view/5634 diakses 10 desember 2019

Firdaus. 2011. Terapi Pijat Untuk kesehatan, Kecerdasan Otak dan Kekuatan Daya Ingat. Yogyakarta:Buku Biru Guyton \& Hall. 2007. Fisiologi kedokteran: EGC

Hastono, Sutanto. 2007. Analisa Data Kesehatan. Jakarta: Universitas Indonesia Henny, Achjar. 2013. Terapi Musik Dan Massase Punggung Terhadap Intensitas Nyeri Sendi Lansia. Poltekes Denpasar. http://poltekkesdenpasar.ac.id/files/ JURNAL\%20GEMA\%20KEPERA WATAN/JUNI\%202013/K.A.\%20 Henny\%20Achjar.pdf diakses 11 desember 2019

Hidayat, A.A. 2009. Metode Penelitian Keperawatan dan Teknik Analisis Data. Jakarta: Salemba Medika

Kenworthy al. 2010. Buku Ajar Keperawatan Medical Bedah. Jakarta:EGC Kristianto, Thomas. 2011. Pengaruh Back Massage Terhadap Intensitas Nyeri Reumatik Pada Lansia Di Wilayah Puskesmas Pembantu Karang Asem. Universitas Muhammadiyah Surakarta. http://eprints.ums.ac.id/18385/1/2._ 
BAGIAN_DEPAN.pdf diakses 11 desember 2019

Kushariyadi dan Setyohadi. 2011. Terapi Modalitas Keperawatan Pada Klien Psikogeriatrik. Jakarta: Salemba Medika.

Similar. 2010. Faktor Resiko Reumatik. http://winapribadi.blogspot.com diakses 16 desember 2019

Smeltzer, Suzanne C dan Brenda G Bare. 2002. Buku Ajar Keperawatan Medikal Bedah Brunner \& Studarth. Jakarta : EGC

Niken. 2015. Pengaruh Stimulasi Kutaneus:Slow Stroke Back Massage Terhadap Intensitas Nyeri Punggung Bawah Pada Lanjut Usia. Stikes Wira Medika PPNI Bali,99,98-102

Notoatmodjo, S. 2010. Metodologi Penelitian. Jakarta

Nugroho, dkk. 2013. Hubungan Antara Beban Kerja Dengan Tingkat Kelelahan Pada Petani Di Desa Curut Kecamatan Penawangan Kabupaten Grobogan Tahun
2013.Universitas Dian Nuswantoro. http://eprints.dinus.ac.id/6499/1/jur nal_12439.pdf diakses 7 januari 2020

Sugiyono. 2014. Metode Penelitian Pendidikan : Pendekatan Kuantitatif, Kualitatif, dan R \& D. Bandung: Alfabeta 
Journal Of Ageing And Family (JOAF)

Edition 1, No 1, October 2021

http://ejournal.urindo.ac.id/index.php/JournalOfAgeingAndFamily/index 